\title{
The Value of Public Safety in Jelenia Góra, Poland
}

\author{
Zbigniew PIEPIORA, Maja KUJAWA \\ Wrocław University of Environmental and Life Sciences, Wrocław, Poland \\ zbigniew.piepiora@upwr.edu.pl \\ kujawa.maja94@gmail.com
}

\begin{abstract}
The aim of article was to answer the research question: did people in Jelenia Góra fear migrants more and value the public safety higher before Warsaw NATO Summit 2016 and 31st World Youth Day than after those events? We have formulated the hypothesis: people in Jelenia Góra feared migrants more and valued higher public safety before Warsaw NATO Summit 2016 and 31st World Youth Day than after those events. To its verification and to answer the research question, we estimated the value of public safety. We used the contingent valuation method. We collected questionnaires during the field work and in the Internet. We conducted first survey on 28 June -7 July 2016 and second one 15-20 November 2016. We did first research before the NATO Summit and the 31st World Youth Day and the next survey after the mentioned events. We selected the Jelenia Góra city because its proximity to the German border which is one of the targets of migration, and to the border with the Czech Republic which is situated close to migration route through Turkey, the Aegean Sea and Greece. The answer to research question is affirmative. The hypothesis was positively verified because the value of public safety in Jelenia Góra before the NATO Summit and the WYD amounted to USD 44895 284, and after those events: USD 41981969.
\end{abstract}

Keywords: Value of Public Safety, WTP, Jelenia Góra.

\section{$1 \quad$ Introduction}

One of EU Eurostat's Quality of life indicators is 'Economic and physical safety'. One of its sub-factors is 'Physical safety' [33]. According Eurostat, a physical safety refers to 'being protected from any situation that puts a person's physical security at risk, such as crime, accidents or natural disasters' [16].

Since beginning of the 21st Century series of terrorist attacks took place in Europe. Some of them were connected with an Islamic state [22, 27]. At the end of 2015, US authorities warned that Isis could print authentic-looking Syrian passports. UK mainstream media warned that i.e. hundreds of migrants arrived in Norway and had mobile phones with images with Isis flags, victims of war and terrorism but pictures could be on phones for innocent reasons $[9,10,35]$.

22 March of 2016, in suicide bombing in Brussels, Belgium, more than 30 people were killed and over 300 injured. The attack was confessed to the Islamic state [30]. 
Shortly thereafter, two major events took place in Poland. On 8-9 July 2016, the NATO Summit took place in Warsaw. In the event attended over 60 countries and international organizations and approx. 2500 delegates, about 1500 media representatives and approx. 500 representatives of scientific and research centres in the field of foreign and security policy. On June 26-31, 2016, the 31st World Youth Day (WYD) was held in the Małopolska Province. In the event participated the Pope Francis, representatives of the Polish Episcopate, the Polish government and the President of the Republic of Poland. Before the NATO Summit and the WYD, in Polish government were fears that terrorist attacks might occur during these events. After the bombing in Brussels, various speculations appeared in Polish media. According to the GCS, fears had the whole of Poland, not only the inhabitants of Warsaw and the Małopolska Province. Thus, the GCS has developed a safety net for the NATO Summit and the WYD [1].

Moreover - Poland, Hungary and the Czech Republic - countries of the Visegrad Group refused EU-imposed refugees. The European Union Commission commenced legal action against Poland over refugees. According to Polish Government Centre for Security (GCS), in the last years the main direction of migrating refugees who left unstable terrains became the route through Turkey, the Aegean Sea and Greece and then further into the territory of the European Union. An important challenge for the migration services has been the lack of verification of the identity of refugees. Most of them had not documents. Even with the strengthening of the Greek services by the Frontex, the verification of the actual basis for granting the protection to the migrants within the European Union has been a constant problem. This involved the risk of using the existing gaps in the system by the emissaries of radical Islamist groups arriving to create the organizational units in Europe, conducting the ideological indoctrination and trainings for terrorists [38].

Above mentioned issues resulted in, that we decided to answer the research question: did people in Jelenia Góra fear migrants more and value the public safety higher before Warsaw NATO Summit 2016 and 31st World Youth Day than after those events? We have formulated the hypothesis: people in Jelenia Góra feared migrants more and valued higher public safety before Warsaw NATO Summit 2016 and 31st World Youth Day than after those events.

For computing, we used the contingent valuation method. We conducted 2 surveys. First was done before the NATO Summit and the WYD and the second one - after the mentioned events. For the research, we have chosen the Jelenia Góra city because of its location near the German border which is one of targets of migration, and with the Czech Republic which is located close to the migration route through Turkey, the Aegean Sea and Greece.

\section{Literature review}

In the end of the 20th century, valuations of public safety values were made by $\mathrm{M}$. Johanesson, P.-O. Johansson, R. M. O'Conor and, later, by H. Andersson, M. 
Svensson and M. Vredin Johansson. They compared the value of public and private safety $[2,23,39]$.

After 11/9/2001, Virginia A. Chanley indicated that shift in public focus from domestic to international concerns was an important factor in the decline in cynicism that occurred after $9 / 11$, and that public support for expending resources to address issues such as homeland security will be greater if increased trust in government can be sustained [11]. S. Sinclair and A. LoCicero indicated that both general terrorism fears and the impact of terror alerts specifically, are statistically significant predictors of trust in government in the tested sample [37].

During the fieldwork period of the European Social Survey occurred the terror attack in Bali on October 12, 2002. Usting this fact, J. Legewie applied a quasiexperimental research design to examine the effect of terrorist events on the perception of immigrants across 65 regions in nine European countries. He revealed the temporal effect [26].

Before and after the Islamic terrorist attacks against railways in Madrid (11 March 2004), A. Echebarria-Echabe and E. Fernandez-Guede did a quasi-experimental study on the effects of terrorism on racial prejudice and ideological orientation. They showed that terrorist attacks provoked changes in a reactionary and conservative direction: stronger prejudices not only against the target group (Arabs), but against another uninvolved group (Jewish); an increase in authoritarianism; stronger attachment to traditional conservative values, and a reduction in the attachment to liberal values. The results are interpreted in terms of the System-Justification Theory, the Motivated Social Cognition model of Conservatism and the Right-Wing Authoritarianism [14].

C. Bozzoli and C. Müller wrote the first paper that uses a terrorist attack, that in the London 7/7/2005, as an exogenous source of variation to study the dynamics of risk perception and the effect on the readiness to trade off civil liberties for enhanced security. They indicated that willingness to trade off security for liberties is dramatically affected by changes in individual risk assessments due to a terrorist attack. We document the extent of persistence of changed attitudes [7]. B. S. Frey, S. Luechinger and A. Stutzer used data from the Euro-Barometer Survey Series to propose the Life Satisfaction Approach. They based on combined cross-section timeseries data and estimated costs of terrorism for France and the British Isles. They estimated costs of terrorism for France and the British Isles [20].

T. Dragu developed a game-theoretic model of an interaction between an antiterrorist agency and aterrorist organization to analyze how the probability of a terrorist attack varies when the level of privacy protections changes. He derived two implications. 1. privacy and security from terrorism need not be in conflict: when accounting for strategic interactions, reducing privacy protections does not necessarily increase security from terrorism. 2. the anti-terrorist agency will always want less privacy [12].

K. Drakos and C. Müller pointed that the observed risk perception variation is significantly explained by the long term terrorism countries face, while the cyclical part of terrorism activity does not affect risk perception [13]. 
S. B. Blomberg, G. D. Hessand and D. Y.J. Tan developed a novel and rich dataset spanning 179 countries from 1968 to 2007 using associated community, social, cultural, political, and economic factors from the World Values Survey and international terrorism incidence data from ITERATE. They proved that terrorism has a negative and statistically significant impact on individual income [6].

T. Brück, F. Llussá and J. A. Tavareset draw on data from the Adult Population Surveys, collected by the Global Entrepreneurship Monitor (GEM) with detailed information on individuals from 43 countries. They found that natural disasters and terrorist attacks influence individual perceptions of the rewards to entrepreneurship. The first ones influence negatively and the last ones positively. More surprisingly, extreme events affect entrepreneurship rates positively in a robust and significant way [8].

H. Finseraas and O. Listhaug identified the causal effect of the Mumbai attacks on public opinion. They exploited the fact that the fourth round of the European Social Survey was conducted in several West European countries at the time of the 2008 terror attacks [18].

A. Economou and C. Kollias used the Eurobarometer Surveys for twelve European Union countries. They employed Ordered Probit models for the period 1985-2010. They used over 230 thousand observations in the estimations. They pointed a shift in respondents' self-positioning towards the right of the political spectrum [15].

P. Arvanitidis, A. Economou and C. Kollias used data drawn from European Social Surveys for the years 2004, 2012 and 2014. They pointed that major terrorist events have the potential to exert significant influence on citizens' risk-perceptions, security sentiments, values and behavioral attitudes towards state institutions and their fellow citizens. They indicated that terrorist incidents can trigger social dynamics that affect trust attitudes; however, these effects are short-lived and dissipate rapidly [3].

\section{$3 \quad$ Methodology and researched area}

The public safety as a good is one of the non-market goods. To determine the value of the public safety we selected the contingent valuation method (CVM) because it is used in situations where market information is limited. In this method, people's opinions about their needs for a given good are collected, assuming that the consumer himself knows what is most rational for him. The questionnaires specify the amount that the individuals are able to pay for access to this good, or assess the amount compensating the loss of using this good. In this way, a hypothetical market is created which determines the willingness of the respondents to pay for the service or good, or the attainment of the purpose, or the compensation for the loss $[5,19,36]$.

There are two variants of the CVM: willingness to pay (WTP) and willingness to accept (WTA). The WTP is the maximum amount that consumers can spend on a good, instead of giving up. The WTA concerns cases when people agree to lose a good. They receive a certain amount of money on the assumption that an individual will retain the same level of welfare that he/she would retain in case of holding the good and not receiving the money. The WTA and WTP notions are the value 
measures of non-market and market goods, or the prosperity of an individual [17, 31, 41].

The CVM is a direct method because it does not use the prices of substitute goods and provides the estimated values of non-marketable environmental goods. It also provides an opportunity to measure a value of the environment, such as the value of existence or use. Its applications are very versatile. These features are considered as the main advantages of this method [21].

For the first time, the CVM was used in the early 1960s. R. Davis used it to calculate the recreational value of the Maine forests in the north-eastern United States. The method developed very dynamically in the 1970s and 1980s. It was used to valuate losses of natural environment caused by executions of various undertakings or by disasters [42]. In Poland, the CVM was first applied in 1993. It was used to estimate the damage caused by the eutrophication of the Baltic Sea. Later, the CVM was used in studies on the protection of the Biebrza Marshes, on the limitation of the car traffic in Kraków, or on the availability of the Oligocene water in Warsaw. In Wroclaw, the research was carried out on the introduction of a newer generation of the municipal waste management system [5].

To response to our research question and to verify our thesis, we selected to estimate the WTP. We have determined how much an inhabitant is able to pay in the form of an annual tax to improve the safety level which determines the value of public safety in the investigated area.

First, we did the literature studies and constructed a survey questionnaire. At the beginning of the survey, we defined safety and public safety. The next step was to ask if the respondent was willing to pay. In the case of an affirmative response, the auction was conducted with the respondent as to the amount that he would be able to pay. Next, we placed a request for a maximum amount. The respondents were also asked about the justification of their choices concerning their willingness to make or not to pay. We also asked them to provide their personal information.

It is worth noting that we have prepared two variants of the survey questionnaire. In variant 1 (before the NATO Summit and the WYD), we pointed out the possible threat of acts of terror during these events. In variant 2 (after the mentioned events) there was not such information. Surveys are available on a request.

Then, we collected questionnaires during the field work and in the Internet. Each of the respondents was informed about the anonymity and confidentiality of the data. We conducted first survey on 28 June -7 July (before the NATO Summit and the WYD) and the second one 15-20 November 2016 (after the mentioned events) [25].

We conducted the surveys in the area of Jelenia Gora. We have chosen this city for research because of its proximity to the German border which is one of the targets of migration, and to the border with the Czech Republic which is situated close to the migration route through Turkey, the Aegean Sea and Greece.

It is worth noting that Jelenia Góra has the status of a city with the district rights after the administrative reforms. It is located in south-western Poland, in the Lower Silesian Province. It lies on the Bóbr river in the Jeleniogórska Valley. The city is also the Polish capital of the Euroregion of Nysa, as well as the seat of the Jelenia Góra 
district and the management of the Karkonosze National Park. The city was also the capital of the Jelenia Góra Voivodeship between 1975 and 1998 [34].

The city's area is $109.22 \mathrm{sq}$. km. The settlement system of the Jelenia Góra city has developed in the form of an elongated strip along the Kamienna, Bóbr and Wrzosówka watercourses [32] in wind less beneficial and unbeneficial zone with temperate climate [24].

In 2016, Jelenia Góra had 80524 inhabitants. The population density in Jelenia Góra is 741 persons per sq. km. The largest number of inhabitants in Jelenia Góra was recorded in 1998 which, according to GUS data, was 93901 inhabitants [4].

The road infrastructure in Jelenia Góra is extensive. There are many roads crossing the city. Main roads are the E65, originating in Chania in Greece, through i.e. the Czech Republic, ending in Scandinavia, and the national road no. 30, connecting Jelenia Gora with Zgorzelec and the Germany. Apart from car routes, there are also railway lines, which communicate the city in directions from i.e. Zgorzelec and Wrocław [40].

In the study, we assumed a confidence level of $95 \%$, a maximum error of $8 \%$, a fraction of 0.5 . With these assumptions the minimum sample size for each sample is 150 people for 80524 inhabitants of Jelenia Gora. The interest rate was set at the reference rate of the NBP, ie 1.5\% [29]. The US dollar-Polish złoty exchange rate was established on the level 3.778 zł per 1 USD [28].

$$
W T P=\left(\frac{W_{W T P}}{n}\right) \cdot L
$$

where: WTP - the willingness to pay (WTP), WWTP - global value of the WTP, n sample size, $\mathrm{L}$ - number of inhabitants of the examined area.

WTP was calculated from the equation 1 . Next, WTP was inserted to equation 2 for the perpetual annuity in the place of the installment amount.

$$
P V=\frac{A}{i}
$$

where: PV - the present value of the perpetuity at the end of a given period, A - the amount of the installment, the value of the previously calculated public safety (WTP).

\section{$4 \quad$ Results and discussion}

As we can see in the table 1, we contacted two independent samples. We collected 150 questionnaires prior to the NATO Summit and the 31st World Youth Day.

Table 1. Summary of survey results.

\begin{tabular}{lll}
\hline Feature & $\begin{array}{l}\text { Survey in the period } \\
\mathbf{2 8 / 6 - 7 / 7 / 2 0 1 6}\end{array}$ & $\begin{array}{l}\text { Survey in the period } \\
\mathbf{1 5 - 2 0 / 1 1 / 2 0 1 6}\end{array}$ \\
\hline Gender & $\begin{array}{l}\text { Female }-87 \text { persons }(58 \%), \text { male }- \\
\text { 63 persons }(42 \%)\end{array}$ & $\begin{array}{l}\text { Female }-90 \text { persons }(60 \%), \\
\text { male }-60 \text { persons }(40 \%)\end{array}$ \\
\hline Age & $0-24$ yrs. -50 persons $(33 \%)$, & $0-24$ yrs. $66-$ persons $(44 \%)$,
\end{tabular}


25-32 yrs. - 47 persons (31\%)

35-44 yrs. - 28 persons (19\%)

45-54 yrs. - 12 persons $(8 \%)$

55-64 yrs. -6 persons (4\%)

64 yrs. and above -7 persons $(5 \%)$

\begin{tabular}{ll}
\hline & 110 persons $(73 \%)$ - Jelenia Góra \\
Occupation & 40 persons $(27 \%)$ - outside JG \\
\hline & Unemployed - 15 persons (10\%) \\
& $\begin{array}{l}\text { Pensioner/annuitant - } 14 \text { persons } \\
(9 \%)\end{array}$ \\
& Student/pupil - 37 persons $(25 \%)$ \\
Employment & Employed - 76 persons $(51 \%)$ \\
& Own business - 8 persons $(5 \%)$
\end{tabular}

Maternity allowance - 0 person $(0 \%)$
25-32 yrs. - 43 persons (29\%)

$35-44$ yrs. - 30 persons (20\%)

45-54 yrs. - 7 persons (5\%)

55-64 yrs. - 1 person (1\%)

64 yrs. and above -3 persons (2\%)

104 persons (69\%) - Jelenia

Góra

46 persons $(31 \%)$ - outside Jelenia Góra

Unemployed - 13 persons

(9\%)

Pensioner/annuitant - 6

persons (4\%)

Student/pupil - 49 persons

(33\%)

Employed - 77 persons (51\%)

Own business - 4 persons (3\%)

Maternity allowance - 1

person $(1 \%)$

Below 750 zł - 21 persons (14\%)

750 zł-1249 zł - 35 persons (23\%)

1250 zł-1749 zł - 30 persons (20\%)

1750 zł-2249 zł - 29 persons (19\%)

Above 2500 - 35 persons (23\%)

\begin{tabular}{lll}
\hline Tax support & 94 persons $(63 \%)$ & $(23 \%)$ \\
\hline & $5 \mathrm{zl}-3$ persons $(2 \%)$ & 77 persons $(51 \%)$ \\
& $10 \mathrm{zl}-28$ persons $(19 \%)$ & $10 \mathrm{zl}-2$ persons $(1 \%)$ \\
& $15 \mathrm{zl}-10$ persons $(7 \%)$ & $15 \mathrm{zl}-9$ persons $(6 \%)$ \\
& $20 \mathrm{zl}-19$ persons $(13 \%)$ & $18 \mathrm{zl}-1$ person $(1 \%)$ \\
WTP & $25 \mathrm{zl}-5$ persons $(3 \%)$ & $20 \mathrm{zl}-17$ persons $(11 \%)$ \\
& $30 \mathrm{zl}-3$ persons $(2 \%)$ & $25 \mathrm{zl}-3$ persons $(2 \%)$ \\
& $40 \mathrm{zl}-1$ person $(1 \%)$ & $30 \mathrm{zl}-7$ persons $(5 \%)$ \\
& $50 \mathrm{zl}-12$ persons $(8 \%)$ & $40 \mathrm{zl}-1$ person $(1 \%)$ \\
$60 \mathrm{zl}-2$ persons $(1 \%)$ & $50 \mathrm{zl}-7$ persons $(5 \%)$ \\
& $100 \mathrm{zl}-9$ persons $(6 \%)$ & $60 \mathrm{zl}-1$ person $(1 \%)$
\end{tabular}


$120 \mathrm{zl}-1$ person $(1 \%)$

$150 \mathrm{zl}-1$ person $(1 \%)$
$75 \mathrm{zl}-1$ person $(1 \%)$

$100 \mathrm{zl}-4$ persons $(3 \%)$

$120 \mathrm{zl}-1$ person $(1 \%)$

$200 \mathrm{zl}-1$ person $(1 \%)$

Considering the table 2, we can see that out of all answers, only 94 people expressed their willingness to pay for the good that the public safety is. The remaining $37 \%$ did not endorse the payment of any fees. The highest value, which was indicated by respondents level-led at $150 \mathrm{zl}$ (USD 39.7). The lowest value amounted to $5 \mathrm{zl}$ (1.323 USD). The most frequent answer was $10 \mathrm{zl}$ (USD 2.65).

Table 2. The results of the research before the NATO Summit and the 31st World Youth Day.

\begin{tabular}{ll}
\hline Feature & Data \\
\hline Number of valid responses & 94 persons \\
Global value & $2970 \mathrm{zł}$ \\
Average & $31.6 \mathrm{zł}$ \\
Maximum value & $150 \mathrm{zł}$ \\
Minimum value & $5 \mathrm{zł}$ \\
Lower quartile & $10 \mathrm{zł}$ \\
Top quartile & $50 \mathrm{zł}$ \\
Median & $20 \mathrm{zl}$ \\
Dominant & $10 \mathrm{zł}$ \\
Standard deviation & $31.18 \mathrm{zł}$ \\
\hline
\end{tabular}

The global value amounted to $2970 \mathrm{zl}$ (USD 786.16). The WTP value was $31.6 \mathrm{zl}$ (8.36 USD) per person. After multiplying this amount by the number of all inhabitants of the investigated area, the WTP value totaled $2544216 \mathrm{zl}$ (USD 673 439.3).

Next, we calculated the value of public safety. It equaled $169614383 \mathrm{zl}$ (44 895284 USD).

After the NATO Summit and the 31st World Youth Day, we collected next 150 questionnaires. Considering the table 3 , we can see that in this case $49 \%$ of respondents did not want to pay for the good. 77 people would like to pay. The maximum amount raised up $200 \mathrm{zl}$ (52.94 US). The lowest amount leveled down to 1 $\mathrm{zl}$ (USD 0.26). The most often indicated amount in the second survey also was $10 \mathrm{zl}$ (USD 2.65).

Table 3. The results of the research after the NATO Summit and the 31st World Youth Day.

\begin{tabular}{ll}
\hline Feature & Data \\
\hline Number of valid responses & 77 persons \\
Global value & $2275 \mathrm{zl}$ \\
Average & $29.55 \mathrm{zl}$
\end{tabular}




\begin{tabular}{ll} 
Maximum value & $200 \mathrm{zl}$ \\
Minimum value & $1.00 \mathrm{zł}$ \\
Lower quartile & $10 \mathrm{zł}$ \\
Top quartile & $30 \mathrm{zł}$ \\
Median & $20 \mathrm{zl}$ \\
Dominant & $10 \mathrm{zł}$ \\
Standard deviation & $33.07 \mathrm{zł}$ \\
\hline
\end{tabular}

The global value equaled $2275 \mathrm{zl}$ (USD 602.17). The WTP value achieved $29.55 \mathrm{zt}$ (USD 7.82) per person. After multiplying this amount by the number of all inhabitants of the examined area, the WTP value totaled 2379118 zt (USD 629 729.5).

Next, we computed the value of public safety. It equaled 158607879 zł (USD 41981969 ).

We noted that the difference between the WTP value before the the NATO Summit and 31st World Youth Day and after those equaled $2.05 \mathrm{zł}$ (USD 0.54) per person. The extension in public safety values exceeded 11 million zł (USD 2913 315). The gap between the number of people who expressed their willingness to pay was 17 . The WTP and the public safety value were higher before the NATO Summit and the WYD. Similarly situation proved to be with the number what would pay the hypothetical tax. Before mentioned events, $63 \%$ of people expressed their payment preferences, and after the events, their number dropped by more than 11 percentage points.

Our research differs in contrast to studies conducted by M. Johanesson, P.-O. Johansson, R. M. O'Conor, H. Andersson, M. Svensson and M. Vredin Johansson $[2,23,39]$ because we have focused only on the public safety.

Our research is complementary to studies of V. A. Chanley, S. Sinclair and A. LoCiceroJ. Legewie, A. Echebarria-Echabe and E. Fernandez-Guede, C. Bozzoli and C. Müller, B. S. Frey, S. Luechinger and A. Stutzer, T. Dragu, K. Drakos and C. Müller, S. B. Blomberg, G. D. Hessand and D. Y.J. Tan, T. Brück, F. Llussá and J. A. Tavareset, H. Finseraas and O. Listhaug, A. Economou and C. Kollias, P. Arvanitidis, A. Economou and C. Kollias [3, 6, 7, 8, 11, 12, 13, 14, 15, 18, 20, 22, 26, 37].

\section{Conclusion}

The aim of the article was to answer the research question: did people in Jelenia Góra fear migrants more and value the public safety higher before Warsaw NATO Summit 2016 and 31st World Youth Day than after those events? Thus, we have formulated the hypothesis: people in Jelenia Góra feared migrants more and valued higher public safety before Warsaw NATO Summit 2016 and 31st World Youth Day than after those events. To answer the research question and verify the thesis, we estimated the value of public safety. 
After conducted analysis, we can draw the following conclusions. The hypothesis was positively verified because the value of public safety in Jelenia Góra before the NATO Summit and 31st World Youth Day amounted to 169614383 (USD 44895 284), and after those events - 158607879 zł (USD 41981 969). Thus, the answer to the research question is affirmative.

The perception and the value of the public safety by the respondents depends on public perception of emergency situations. In the case of the terrorism hazard, people are able to spend more money to be secured and level up the safety.

It is worth noting that the results presented in this study are estimated and hypothetical. The valuation has made it possible to indicate the importance of the public safety for the respondents and varying its value depending on the situation in which were the examined people.

In the future, we shall do the next research to compare the public safety value for Poland, Hungary and the Czech Republic with costs of not accepting by these countries the refugees as part of a program to relocate asylum seekers residing in camps located in Greece and Italy.

Acknowledgements. We benefited from comments of C. Kollias - the editor of 'Defence and Peace Economics' and anonymous referee - member of 'Defence and Peace Economics' Editorial Board.

\section{References}

1. Adamkiewicz, A., Zasadzińska-Baraniewska, A., Sobolewski, M.: Działania Rządowego Centrum Bezpieczeństwa związane ze Szczytem NATO i 31. Światowymi Dniami Młodzieży. In: M. Olejnik, A.: Zasadzińska-Baraniewska. Biuletyn Kwartalny 14, pp. 3-5. Rządowe Centrum Bezpieczeństwa, Warsaw (2016).

2. Swedish National Road and Transport Research Institute (VTI): Private and Public WTP for Safety - A Validity Test, http://www.transportportal.se /SWoPEc/Andersson_Public_Private.pdf, last accessed 2017/06/12.

3. Arvanitidis, P., Economou, A., Kollias, C.: Terrorism's effects on social capital in European countries. Public Choice 169(4), 231-250 (2016), DOI: 10.1007/s11127-0160370-3.

4. BDL GUS, https://bdl.stat.gov.p1/BDL/dane/podgrup/tablica, last accessed 2017/06/12.

5. Becla, A., Czaja, S., Zielińska, A.: Analiza kosztów-korzyści w wycenie środowiska przyrodniczego, Difin, Warsaw (2012).

6. Blomberg, S. B., Hessand, G. D., Tan, D Y.J.: Terrorism and the economics of trust. Journal of Peace Research 48(3), 383-398 (2011).

7. Bozzoli, C., Mülle,r C.: Perceptions and attitudes following a terrorist shock: Evidence from the UK. European Journal of Political Economy 27, 89-106 (2011), DOI:10.1016/j.ejpoleco.2011.06.005

8. Brück, T., Llussá, F., Tavareset, J. A.: Entrepreneurship: The Role of Extreme Events. European Journal of Political Economy 27, 78-88 (2011), DOI: 10.1016/j.ejpoleco.2011.08.002. 
9. ISIS filth found on phones of hundreds of migrants entering EU - next stop London?, http://www.express.co.uk/news/world/626925/ISIS-Islamic-State-Flag-Migrants-EuropeNorway-Severed-Heads-Schengen-EU-Jihadi, last accessed 2015/12/15.

10. Hundreds of migrants arriving in Norway had mobile phones containing images of executions, severed heads and dead children, police reveal, http://www.dailymail.co.uk/news/article-3359901/Hundreds-migrants-arriving-Norwaymobile-phones-containing-images-executions-severed-heads-dead-children-policereveal.html, last accessed 2015/12/14.

11. Chanley, V. A.: Trust in government in the aftermath of 9/11: Determinants and consequences. Political Psychology 23(3), 469-483 (2002), DOI: 10.1111/0162895X.00294.

12. Dragu, T.: Is there a Trade-off Between Security and Liberty? Executive Bias, Privacy Protections and Terrorism Prevention. American Political Science Review 105, 4-78 (2011), DOI: 10.1017/S0003055410000614.

13. Drakos, K., Müller, C.: Terrorism Risk Concern in Europe. Economics Letters 112(2), 195-197 (2011), DOI:10.1016/j.econlet.2011.04.003.

14. Echebarria-Echabe, A., Fernandez-Guede, E.: Effects of terrorism on attitudes and ideological orientation. European Journal of Social Psychology 36(2), 259-265 (2006), DOI: $10.1002 /$ ejsp.294.

15. Economou, A., Kollias, C.: Terrorism and political self-placement in European Union countries. Peace Economics, Peace Science and Public Policy 21(2), 217-238 (2015), DOI: $10.1515 /$ peps-2014-0036.

16. Eurostat: Quality of life indicators - economic and physical safety, http://ec.europa.eu/eurostat/statistics-explained/index.php/Quality_of_life_indicators__economic_and_physical_safety, last accessed 2017/10/26.

17. Famielec, J.: Straty i korzyści ekologiczne w gospodarce narodowej. PWN, Warsaw (1999).

18. Finseraas, H., Listhaug, O.: It Can Happen Here: The Impact of the Mumbai Terror Attacks on Public Opinion in Western Europe. Public Choice 156, 213-228 (2013), DOI: 10.1007/s11127-011-9825-7.

19. Folmer, H., Gaber, L., Opschoor F.: Principles of environmental and resource economics: a guide for students and decision-makers. Elgar, Aldershot (1995).

20. Frey, B. S., Luechinger, S., Stutzer, A.: The life satisfaction approach to valuing public goods: The case of terrorism. Public Choice 138, 317-345 (2009), DOI 10.1007/s11127008-9361-3.

21. Graczyk, A.: Ekologiczne koszty zewnętrzne: Identyfikacja, szacowanie, interna-lizacja. Ekonomia i Środowisko, Białystok (2006).

22. Jakobsson, N., Blom, S.: Did the 2011 terror attacks in Norway change citizens' attitudes toward immigrants? International Journal of Public Opinion Research 26(4), 475-486 (2014), DOI: 10.1093/ijpor/edt036.

23. Johanesson, M., Johansson, P.O., O'Conor, R. M.: The Value of Private Safety Versus the Value of Public Safety. Journal of Risk and Uncertainty 13, 263-275 (1996), DOI: 10.1007/BF00056156.

24. Kazak, J., van Hoof, J., Szewrański, Sz.: Challenges in the wind turbines location process in Central Europe - The use of spatial decision support systems. Renewable and Sustainable Energy Reviews 76, 425-433 (2017), DOI: 10.1016/j.rser.2017.03.039.

25. Kujawa, M.: Zastosowanie metody wyceny warunkowej do określenia wartości bezpieczeństwa na przykładzie miasta Jelenia Góra. Wrocław University of Environmental and Life Sciences, Wrocław (2016). 
26. Legewie, J.: Terrorist events and attitudes toward immigrants: A natural experiment. American Journal of Sociology 118(5), 1199-1245 (2013), DOI: 10.1086/669605.

27. Najważniejsze zamachy terrorystyczne w Europie w ostatnich latach - dokumentacja http://www.gazetaprawna.pl/artykuly/1048402,zamachy-terrorystyczne-w-europie-wostatnich-latach.html, last accessed 23/10/2017.

28. NBP: Kursy walut, http://www.nbp.pl/home.aspx?f=/kursy/kursyc.html, last accessed 2017/06/13.

29. NBP: Podstawowe stopy procentowe, www.nbp.pl/home.aspx?f=/dzienne/stopy.htm, last accessed 2017/06/12.

30. Paszkowski, A.: Zamachy terrorystyczne w Brukseli. In: M. Olejnik, A.: ZasadzińskaBaraniewska. Biuletyn Kwartalny 14, pp. 9-12. Rządowe Centrum Bezpieczeństwa, Warsaw (2016).

31. Piepiora, Z. N., Godlewska, M. E.: Określenie rekreacyjnej wartości Tatrzańskiego Parku Narodowego metodą wyceny warunkowej i metodą kosztów podróży. In: S. Winiarski, A. Struzik (eds.), Ogólnopolska Konferencja dla Młodych Naukowców Wieczór Naukowca 2017 wokół człowieka, pp. 62-63, AWF, Wrocław (2017).

32. Piepiora, Z., Belarga, O.: The local disaster management system: the crisis cluster in the face of natural disasters. In: 3rd HASSACC 2015 - Virtual Conference Human And Social Sciences at the Common Conference 5-9 October, 2015, HASSACC - Human And Social Sciences at the Common Conference (Proceedings detailed information) 3(1), pp. 90-93, EDIS, Zilina (2015).

33. Piepior,a Z, Morawsk,i M., Kachniarz, M.: Financing emergency management as an factor of quality of life in the face of natural disasters - the case study of Poland. European Journal of Business Research ${ }^{\circledR}$ 17(1), 57-62 (2017), DOI: 10/18374/EJBR-17-1.6.

34. Przybyła, K., Kulczyk-Dynowska, A., Kachniarz, M.: Quality of Life in the Regional Capitals of Poland, Journal of Economic Issues 48(1), 181-195 (2014), DOI: 10.2753/JEI0021-3624480109.

35. Thousands of Isil fighters could use migrant crisis to 'flood' into Europe, Nigel Farage warns, http://www.telegraph.co.uk/news/politics/nigel-farage/11844290/Thousands-of-Isilfighters-could-use-migrant-crisis-to-flood-into-Europe-Nigel-Farage-warns.html, last accessed 2015/09/04.

36. Rogall, H.: Nachhaltige Ökonomie. Ökonomische Theorie und Praxis einer Nachhaltigen Entwicklung. Metropolis, Marburg (2012).

37. Sinclair, S., LoCicero, A.: Do fears of terrorism predict trust in government? Journal of Aggression, Conflict and Peace Research 2(1), 57-68 (2010), DOI: 10.5042/jacpr.2010.0005.

38. Szaciłło, M.: Prognoza kształtowania się w Europie szlaku migracyjnego z Bliskiego Wschodu w perspektywie 2016 r. In: M. Olejnik, A.: Zasadzińska-Baraniewska. Biuletyn Kwartalny 14, pp. 6-8. Rządowe Centrum Bezpieczeństwa, Warsaw (2016).

39. Svensson, M., Johansson, M. V.: Willingness to pay for private and public road safety in stated preference studies: Why the difference? Accident Analysis \& Prevention 42(4), 1205-1212 (2010), doi:10.1016/j.aap.2010.01.012.

40. Uchwała nr 245.XXXIV.2016 Rady Miejskiej Jeleniej Góry z dnia 8 listopada 2016 roku w sprawie uchwalenia studium uwarunkowań i kierunków zagospodarowania przestrzennego miasta Jelenia Góra, http://bip.jeleniagora.pl/contents/content/91/350, last accessed 2017/06/12.

41. Winpenny, J. T.: Values for the Environment. A guide to Economic Appraisal. H.M. Stationery Office, London (1991). 
42. Zawilińska, B.: Ekonomiczna wartość obszarów chronionych. Zarys problematyki I metodyka badań. Zeszyty Naukowe Uniwersytet Ekonomiczny w Krakowie 12, 122-123 (2014), DOI: 19.15678/znuek.2014.0936.1208. 